\title{
Taxonomic Analysis of Thermophilic Strains of the Genus Methanobacterium: Reclassification of Methanobacterium thermoalcaliphilum as a Synonym of Methanobacterium thermoautotrophicum
}

\author{
S. V. KOTELNIKOVA, ${ }^{1 *}$ A. Y. OBRAZTSOVA, ${ }^{1}$ K.-H. BLOTEVOGEL, ${ }^{2}$ AND I. N. POPOV ${ }^{1}$ \\ Institute of Biochemistry and Physiology of Microorganisms, 142292, Pushchino, Moscow Region, Prospect \\ Nauki, 5, Russia, ${ }^{1}$ and Universität Oldenburg, Fb7 Mikrobiologie, 2900 Oldenburg, Germany ${ }^{2}$
}

\begin{abstract}
DNA reassociation, a comparative analysis of whole-cell protein patterns, and indirect immunofluorescence methods were used to determine the taxonomic relationships of thermophilic Methanobacterium strains. On the basis of the results dendrograms showing degrees of similarity among the organisms were constructed. The organisms studied are members of three different groups. One group, whose members exhibit 10 to $40 \%$ cross-hybridization, includes Methanobacterium wolfeii, "Methanobacterium defluvium" ADZ, and "Methanobacterium thermoflexum" IDZ. The second group contains Methanobacterium thermophilum $\mathbf{M}^{\mathbf{T}}(\mathrm{T}=\mathrm{type}$ strain) and Methanobacterium thermoaggregans (levels of DNA relatedness, 30 to $45 \%$ ). The third group, whose members exhibit 65 to $99 \%$ cross-hybridization, includes Methanobacterium thermoautotrophicum $\Delta \mathbf{H}^{\mathrm{T}}, \mathbf{F}-1$, and DV; Methanobacterium thermoformicicum $\mathrm{Z-245}^{\mathrm{T}}$; and Methanobacterium thermoalcaliphilum AC60 ${ }^{\mathrm{T}}$. The combination of three independent taxonomic methods showed that the group of strains studied is phenotypically, genotypically, and antigenically diverse. The most distinct organisms are $M$. wolfeii, $M$. thermoaggregans, $M$. thermophilum, “M. defluvium," "M. thermoflexum," and $M$. thermoautotrophicum. These species names should be adopted. The results of a DNA-DNA hybridization study (level of hybridization, $99 \%$ ), an immunological analysis ( +3 reaction), and a protein similarity study (level of similarity, $75 \%$ ) indicate that $M$. thermoalcaliphilum should be reclassified as a synonym of $M$. thermoautotrophicum.
\end{abstract}

The taxonomy of methanogenic bacteria has been revised on the basis of new data obtained from comparative analysis of 16S rRNA oligonucleotides (1), studies of cell wall structure (13) and polyamines (24), immunological analysis (17), and DNA-DNA hybridization $(25,31)$. Phenotypic characteristics alone do not provide sufficient grounds for subdivision of taxa and estimation of the phylogenetic positions of methanogenic bacteria (5). The predominant factors now used in the taxonomy of methanogens are chemotaxonomic and molecular genetic features.

Currently, the genus Methanobacterium includes 13 species of rod-shaped, $\mathrm{H}_{2}-\mathrm{CO}_{2}$-consuming methanogens (11, 16). These species were classified on the basis of their $\mathrm{pH}$ and temperature optima and capacity to utilize formate. Also, obligate requirements for growth factors, $\mathrm{G}+\mathrm{C}$ contents of DNAs, and antigenic differences were used for identification (5). The thermophilic members of the genus Methanobacterium include organisms that grow at 40 to $75^{\circ} \mathrm{C}$. These bacteria exhibit high levels of phenotypic similarity. They have similar physiological properties and similar morphology and use the same substrates $(3,4,14,16,29,32$, 33). The relationships of some thermophilic methanogens belonging to the genus Methanobacterium have been analyzed previously $(6,27)$. The thermophilic strains Methanobacterium thermoautotrophicum $\Delta \mathrm{H}^{\mathrm{T}}(\mathrm{T}=$ type strain) and Marburg belong to different genogroups or even species (6). The taxonomic positions of thermophilic, formate-utilizing strains FTF, THF, CB-12, and Marburg and Methanobacterium thermoformicicum $\mathrm{Z}-245^{\mathrm{T}}$ were studied by Touzel et al. (27). These organisms belong to different taxonomic groups. $M$. thermoformicicum $\mathrm{Z}-245^{\mathrm{T}}$ is antigenically and genotypi-

\footnotetext{
* Corresponding author.
}

cally similar to $M$. thermoautotrophicum strains $(2,27)$. Thus, the taxonomic relationships of thermophilic Methanobacterium species need further analysis. In this paper we present data which elucidate the taxonomic relationships of newly isolated and known thermophilic Methanobacterium strains. In our investigation we used a combination of methods, including DNA hybridization, numerical analysis of whole-cell protein patterns, and antigenic fingerprinting.

\section{MATERIALS AND METHODS}

Microorganisms. The organisms used in this study are listed in Table 1.

Media and growth conditions. The anaerobic techniques described by Balch et al. (1) were used. Cultures were grown in a medium containing (per liter) $1.0 \mathrm{~g}$ of $\mathrm{NH}_{4} \mathrm{Cl}, 0.2 \mathrm{~g}$ of $\mathrm{MgCl}_{2} \cdot \mathrm{H}_{2} \mathrm{O}, 0.1 \mathrm{~g}$ of $\mathrm{CaCl}_{2} \cdot 6 \mathrm{H}_{2} \mathrm{O}, 0.9 \mathrm{~g}$ of $\mathrm{NaCl}, 2 \mathrm{~g}$ of yeast extract, $0.2 \mathrm{~g}$ of $\mathrm{K}_{2} \mathrm{HPO}_{4}, 0.1 \mathrm{~g}$ of $\mathrm{KH}_{2} \mathrm{PO}_{4}, 0.002 \mathrm{~g}$ of resazurin, $10 \mathrm{ml}$ of mineral solution SL-6 (30), $5 \mathrm{ml}$ of a vitamin solution (30), $0.5 \mathrm{~g}$ of $\mathrm{L}$-cysteine- $\mathrm{HCl}$, and $0.5 \mathrm{~g}$ of $\mathrm{Na}_{2} \mathrm{~S} \cdot 9 \mathrm{H}_{2} \mathrm{O}$. The final pH was 7.2 to 7.4. An $\mathrm{H}_{2}-\mathrm{CO}_{2}$ mixture (80:20) was used as the gas phase. Each sterile medium preparation was inoculated with $5 \%$ (vol/vol) of the previous culture. Organisms were mass cultured in 1-liter flasks in the same medium with sparging of $\mathrm{H}_{2}-\mathrm{CO}_{2}$.

Determination of DNA base composition. Frozen cells ( 1 to $2 \mathrm{~g}$ ) were disrupted by using an Institute of Biochemistry and Physiology of Microorganisms press at 3,500 atm $\left(3.5 \times 10^{5}\right.$ $\mathrm{kPa})$ and $-25^{\circ} \mathrm{C}$. The DNA was isolated by the Marmur method (18). The $\mathrm{G}+\mathrm{C}$ content of the DNA was determined by a melting point analysis (19), using the DNA of the Escherichia coli $\mathrm{K}-12(51 \mathrm{~mol} \% \mathrm{G}+\mathrm{C})$ as a reference. The DNA was dissolved in citrate buffer $(0.1 \times$ SSC; $1 \times$ SSC is $0.15 \mathrm{M} \mathrm{NaCl}$ plus $0.015 \mathrm{M}$ trisodium citrate 2-hydrate $[\mathrm{pH}$ 
TABLE 1. Thermophilic methanogens used in this study

\begin{tabular}{|c|c|c|c|}
\hline \multirow{2}{*}{ Organism } & \multicolumn{2}{|c|}{ Collection no. ${ }^{a}$} & \multirow{2}{*}{ Source $^{a}$} \\
\hline & DSM & VKM & \\
\hline M. thermoautotrophicum $\Delta \mathrm{H}^{\mathrm{T}}$ & $1053^{\mathrm{T}}$ & $1908^{\mathrm{T}}$ & $\overline{\mathrm{VKM}}$ \\
\hline M. thermoformicicum $\mathrm{Z}-245^{\mathrm{T}}$ & $2720^{\mathrm{T}}$ & & Zhilina \\
\hline$M$. thermoaggregans & $3266^{\mathrm{T}}$ & $1959^{\mathrm{T}}$ & Blotevogel \\
\hline M. wolfeii & $2970^{\mathrm{T}}$ & $1829^{\mathrm{T}}$ & VKM \\
\hline M. thermoalcaliphilum $\mathrm{AC} 60^{\mathrm{T}}$ & $3267^{\mathrm{T}}$ & $1958^{\mathrm{T}}$ & Blotevogel \\
\hline M. thermophilum $\mathrm{M}^{\mathrm{T}}$ & $3530^{\mathrm{T}}$ & $1786^{\mathrm{T}}$ & VKM \\
\hline "M. defluvium" $\mathrm{ADZ}$ & & 1962 & VKM \\
\hline "M. thermoflexum" IDZ & & 1963 & VKM \\
\hline Methanobacterium sp. strain DV & & 1851 & VKM \\
\hline Methanobacterium sp. strain F-1 & & 1852 & VKM \\
\hline Methanobacterium sp. strain Z-1201 & & 1961 & Zhilina \\
\hline Methanobacterium sp. strain Z-1901 & & 1960 & Zhilina \\
\hline Methanobacterium sp. strain 7VF & & 1964 & VKM \\
\hline
\end{tabular}

${ }^{a}$ VKM, All-Russian Collection of Microorganisms, Pushchino, Moscow Region, Russia; DSM, Deutsche Sammlung von Mikroorganismen und Zellkulturen, Braunschweig-Stockheim, Germany; Blotevogel, K.-H. Blotevogel, Universitat Oldenburg, Oldenburg, Germany; Zhilina, T. N. Zhilina, Institute of Microbiology, Moscow, Russia.

7.0]). The DNA was previously dialyzed with the same buffer. $A_{260}$ and cell temperature were digitally recorded at 0.5 -min intervals with a thermoprogrammer.

DNA-DNA hybridization. Levels of DNA hybridization were determined spectrophotometrically from the initial renaturation rates by the method of De Ley et al. (9). The DNA samples were sonicated at $0^{\circ} \mathrm{C}$ for $20 \mathrm{~min}$ with an Ultrasonic MSE disintegrator. The average molecular weight of DNA fragments was constant for different DNA samples and fell with the limits of $400,000 \pm 50,000$. The total DNA concentration was $75 \mathrm{mg} / \mathrm{ml}$. The optimal renaturation temperature in $2 \times \mathrm{SSC}$ was $70^{\circ} \mathrm{C}$. A model DU-8B spectrophotometer (Beckman) equipped with a thermoprogrammer and a thermostatically controlled cuvette chamber was used.

Immunological fingerprints. The antigenic fingerprints of strains were determined by using antisera against eight thermophilic methanogens (Table 1). Antigenic relatedness was studied by the indirect immunofluorescence method (7).

Cell protein analysis. Whole-cell proteins were analyzed by using the Laemmli method (15). Cells from 18-h-old cultures were harvested by centrifugation at $15,000 \times g$ for $15 \mathrm{~min}$, washed twice with a $50 \mathrm{mM}$ phosphate buffer

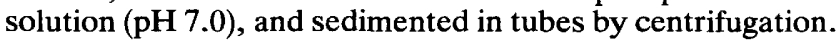
Then the cells were suspended in $0.5 \mathrm{ml}$ of sample buffer $(\mathrm{pH}$ 6.8 ) containing $0.0625 \mathrm{mM}$ Tris, $5 \%$ 2-mercaptoethanol, $10 \%$ glycerol, and $2 \%$ sodium dodecyl sulfate and sonicated at $1^{\circ} \mathrm{C}$ for $10 \mathrm{~min}$ with an Ultrasonic MSE disintegrator. The cellular debris were removed by centrifugation at $15,000 \times g$ for $15 \mathrm{~min}$. After protein denaturation by heating $\left(100^{\circ} \mathrm{C}, 5\right.$ min) in the sample buffer, samples were analyzed by electrophoresis in a polyacrylamide slab gel by using a $4 \%$ stacking gel ( $\mathrm{pH} 6.8$ ) and a 9 to $22.5 \%$ gradient separating gel (pH 8.8). The ratio of acrylamide to bisacrylamide in the gel was $10: 2.7$. Electrophoresis was performed at $5^{\circ} \mathrm{C}$ for $20 \mathrm{~min}$ at an initial voltage of $60 \mathrm{~V}$ and for $6 \mathrm{~h}$ at a voltage of $120 \mathrm{~V}$. The gel format was 160 by $120 \mathrm{~mm}$. The gel was stained with $1 \%$ Coomassie blue G-250 in a $50 \%$ methanol-10\% acetic acid solution. Gel densitometry was performed with a model 2202 Ultrascan-Laser densitometer (LKB-Bromma). The gels were standardized by using molecular weight standards. The molecular weight standards used were bovine albumin (molecular weight, 67,000), egg albumin (45,000), lactate dehydrogenase $(36,000)$, chymotrypsin $(25,000)$, and trypsin inhibitor $(20,000)$. The standardization procedures used were similar to those proposed by Kersters and De Ley (12). Attention was paid to compensating for misalignments of the gels. By taking into account the differences between peak positions of molecular weight standards placed at several sample positions on the gel, the compensation coefficients were calculated individually for every sample lane. By comparing the profiles of the same organisms on different gels, we found that the peak positions could be determined with a level of accuracy of $\pm 1 \mathrm{kDa}$. This value was chosen as the criterion for peak coincidence.

Taxonomic analysis. A cluster analysis of DNA-DNA homology values and whole-cell protein patterns was carried out by using a program developed by I. Popov. The similarity coefficients for the protein peak patterns were calculated by the following formula: $C_{s}=a /[(b+c) / 2]$, where $a$ is the number of coinciding peaks and $b$ and $c$ are the total numbers of peaks for two samples.

The dendrograms were constructed by using the unweighted pair group method for arithmetic averages. The dendrograms were made as follows. The program searched for the most similar pair in the similarity table. Then this pair was treated as a new member of the table that was substituted for the two former members. The levels of similarity were recalculated taking into account the weights of the elements of the pair. Thus, when a cluster was paired with an initial element (i.e., a strain) or another cluster, the level of similarity of the resulting cluster to that of another member reflected equally the properties of all of the initial elements clustered in the paired members.

\section{RESULTS AND DISCUSSION}

G + C content of DNA. The DNA base compositions of thermophilic Methanobacterium strains ranged from 48 to 62 mol\% G+C (Table 2). The value obtained by us for $M$. thermoautotrophicum $\Delta H^{\mathrm{T}}$ was $50.7 \mathrm{~mol} \% \mathrm{G}+\mathrm{C}$, which is close to values reported by other authors. A value of 52 mol\% was reported for strain $\mathbf{H}^{\mathrm{T}}$ by Zeikus and Wolfe (32) (determined by buoyant density in $\mathrm{CsCl}$ ), a value of 49.4 mol\% was reported by Mitchell et al. (20), and a value of 48.6 mol\% was reported by Brandis et al. (6) (determined by thermal denaturation). The $\mathrm{G}+\mathrm{C}$ content of the DNA of $M$. thermoformicicum $\mathrm{Z}-245^{\mathrm{T}}$ was $50.6 \mathrm{~mol} \%$; this is similar to the value determined by Touzel et al. (27) (48.8 mol\%). The DNA base compositions of Methanobacterium thermoaggregans and Methanobacterium thermoalcaliphilum were 47.9 and $49.8 \mathrm{~mol} \% \mathrm{G}+\mathrm{C}$, respectively; these values were greater than the values obtained by Blotevogel et al. (4) and Blotevogel and Fischer (3).

DNA relatedness. The levels of DNA relatedness of 10 thermophilic Methanobacterium strains were calculated from the rates of DNA renaturation (Table 2). On the basis of the DNA hybridization results, a dendrogram showing the degrees of similarity between the organisms was constructed (Fig. 1).

"Methanobacterium thermoflexum" IDZ, "Methanobacterium defluvium" $\mathrm{ADZ}$, and Methanobacterium wolfeii exhibited levels of DNA homology of 10 to $46 \%$ with each other and only $20 \%$ with the other organisms tested. " $M$. thermoflexum" IDZ and " $M$. defluvium" ADZ were described as separate species (14). This group contains organisms that are not very closely related. To facilitate the 
TABLE 2. DNA base compositions and levels of DNA-DNA hybridization of thermophilic Methanobacterium strains

\begin{tabular}{|c|c|c|c|c|c|c|c|c|c|c|c|}
\hline \multirow[b]{2}{*}{ Strain } & \multirow{2}{*}{$\begin{array}{c}\mathrm{G}+\mathrm{C} \\
\text { content } \\
(\mathrm{mol} \%)^{a}\end{array}$} & \multicolumn{10}{|c|}{$\%$ Hybridization with DNA from strain ${ }^{b}$ : } \\
\hline & & $\mathbf{M}^{\mathrm{T}}$ & DV & $\Delta \mathbf{H}^{\mathrm{T}}$ & $\mathrm{Z}-245^{\mathrm{T}}$ & $\mathrm{AC}^{\mathrm{T}}$ & $\begin{array}{l}\mathrm{DSM} \\
3266^{\mathrm{T}}\end{array}$ & $\begin{array}{c}\text { DSM } \\
2970^{\mathrm{T}}\end{array}$ & F-1 & $\mathrm{ADZ}$ & IDZ \\
\hline M. thermophilum $\mathrm{M}^{\mathrm{T}}$ & 48.4 & $100^{\circ}$ & $47.2^{a}$ & 18.1 & 45.4 & 22.7 & 46.4 & 13.8 & 32.2 & 22.2 & 10.2 \\
\hline M. thermoautotrophicum DV & 49.99 & & 100 & 63.0 & 73.8 & 69.2 & 39.0 & 10.4 & 54.0 & 24.0 & 45.3 \\
\hline M. thermoautotrophicum $\Delta \mathrm{H}^{\mathrm{T}}$ & 50.78 & & & 100 & 99.5 & 99.6 & 36.3 & 20.5 & 76.4 & 38.7 & 43.5 \\
\hline M. thermoformicicum Z-245 & 50.59 & & & & 100 & 91.4 & 31.4 & 32.1 & 91.7 & 44.7 & 44.3 \\
\hline M. thermoalcaliphilum AC $60^{\mathrm{T}}$ & 49.8 & & & & & 100 & 37.6 & 25.0 & 98.0 & 29.4 & 34.6 \\
\hline M. thermoaggregans DSM $3266^{\mathrm{T}}$ & 47.9 & & & & & & 100 & 34.0 & 39.0 & 42.4 & 32.0 \\
\hline M. wolfeii DSM $2970^{\mathrm{T}}$ & 48.5 & & & & & & & 100 & 6.3 & 25.7 & 15.0 \\
\hline M. thermoautothrophicum F-1 & 50.5 & & & & & & & & 100 & 27.5 & 12.0 \\
\hline "M. defluvium" $\mathrm{ADZ}$ & 62.2 & & & & & & & & & 100 & 46.9 \\
\hline "M. thermoflexum" IDZ & 55.0 & & & & & & & & & & 100 \\
\hline
\end{tabular}

a Our data.

${ }^{b}$ Each assay was performed three times with two different hybridization preparations.

${ }^{c}$ Homologous reaction.

following analysis, we designated this group cluster I for convenience.

A second cluster includes Methanobacterium thermophilum and $M$. thermoaggregans, which exhibit levels of homology with other Methanobacterium strains of about $33 \%$. This group contains organisms that exhibit $45 \%$ DNADNA hybridization with each other.

A third group, with levels of cross-hybridization of 65 to $99 \%$, includes $M$. thermoautotrophicum $\Delta \mathrm{H}^{\mathrm{T}}, M$. thermoformicicum Z-245 ${ }^{\mathrm{T}}, \mathrm{DV}$, and $\mathrm{F}-1$, and $M$. thermoalcaliphilum $\mathrm{AC} 60^{\mathrm{T}}$. This cluster branches from the other organisms at a level of 20 to $30 \%$ (Fig. 1).

The interspecies levels of binding in Methanobacterium spp. ranged from 10 to $45 \%$. Despite phenotypic similarities (Table 3 ), this group is genetically diverse.

Numerical analysis of whole-cell protein profiles. The whole-cell protein profiles, which were used for comparison, consisted of 20 to 30 discrete protein bands in the molecular mass range from 14 to $90 \mathrm{kDa}$ (Fig. 2). The levels of reproducibility were estimated by calculating the similarity coefficients $\left(C_{s}\right)$ for the same-strain protein profiles on five different slab gels, each of which included three molecular weight reference lanes. The level of reproducibility $\left(C_{s}\right)$ for the protein patterns of strain DV, including one pattern on each gel, was $>0.95$. The $C_{s}$ for the molecular weight marker lanes was $>0.92$.

A comparative analysis of total protein contents by electrophoresis followed by processing of the final results with a computer program was carried out for the 13 thermophilic Methanobacterium strains. On this basis the following $C_{s}$ values were obtained: 0.50 to 0.75 at the intraspecies level and 0.40 to 0.50 at the interspecies level. The organisms tested were divided into three clusters (Fig. 3). The resulting dendrogram shows that the cluster that includes $M$. wolfeii, " $M$. thermoflexum," and " $M$. defluvium" branches at a $C_{s}$ level of 0.4. $M$. thermoaggregans, and $M$. thermophilum exhibit a $C_{s}$ of 0.45 with the other organisms tested. For $M$. thermoformicicum Z-245 ${ }^{\mathrm{T}}$ and Methanobacterium sp. strains $7 \mathrm{VF}, \mathrm{F}-1$, and $\mathrm{Z}-1201$ the $C_{s}$ value is $0.55 . M$. thermoautotrophicum $\Delta \mathrm{H}^{\mathrm{T}}$ and $M$. thermoalcaliphilum $\mathrm{AC}^{\mathrm{T}}$ have a $C_{s}$ of 0.75 .

The results of the protein analysis are in accord with the DNA-DNA hybridization data (Fig. 1 and 3). The interspecies protein homology levels (40 to $50 \%$ ) are higher than the DNA-DNA hybridization homology levels (10 to $45 \%$ ) in the strains studied. This phenomenon may be explained by the limited number of genes, which were transcribed under definite conditions of regulation, as sho a by the number of protein bands present in the electrophoretic profiles of cells (Fig. 2).

Whole-cell protein analysis was also used in combination with DNA-DNA relatedness studies to elucidate finer interand intraspecific relationships of Oceanospirillum strains (23) and to compare Pseudomonas spp. with allied bacteria (22) and Acinetobacter strains (10).

Our DNA-DNA hybridization result for $M$. thermoformicicum $\mathrm{Z}-245^{\mathrm{T}}$ and $M$. thermoautotrophicum $\Delta \mathrm{H}^{\mathrm{T}}$ (level of homology, 99\%) is in accord with the results reported by Touzel et al. (27); however, the protein $C_{s}$ value for these organisms $(75 \%)$ is lower than the DNA-DNA homology value. This may be due to the presence of plasmid pFZ1 in cells of strain $\mathrm{Z}-245^{\mathrm{T}}$ (21). It is possible that the heterogeneous proteins observed in these organisms are determined by extrachromosomal DNA, which is responsible for formate consumption.

Numerical analysis of whole-cell protein profiles of some methanogens has been used in a taxonomic study by Thomas et al. (26). Our similarity dendrogram is very similar to the dendrogram constructed from the Pearson coefficient matrix by Thomas et al. (26). For example, these authors showed that thermophilic strains $M$. thermoautotrophicum $\Delta \mathbf{H}^{\mathrm{T}}$ and

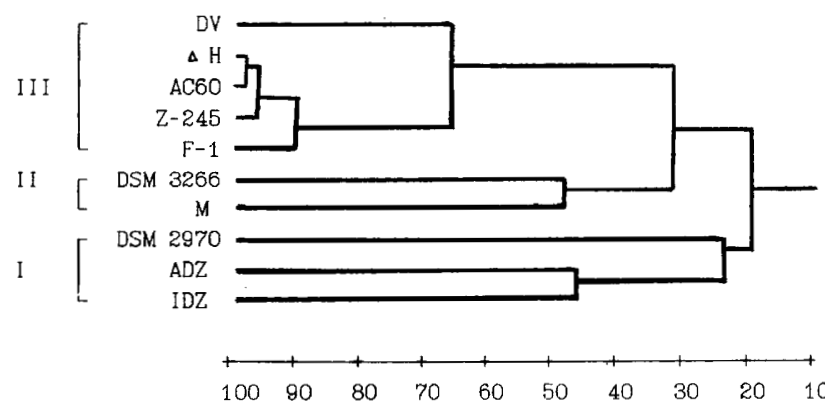

DNA-DNA hybridization, percentage

FIG. 1. Dendrogram showing levels of DNA relatedness among members of the 10-strain matrix. Clustering was accomplished by using the unweighted average linkage algorithm. The roman numerals indicate clusters. The species assignments of the strains are shown in Table 1. 
TABLE 3. Comparison of main characteristics of thermophilic rod-shaped methanogenic bacteria

\begin{tabular}{|c|c|c|c|c|c|c|c|c|}
\hline \multirow[b]{2}{*}{ Species or strain } & \multirow[b]{2}{*}{ Group } & \multirow{2}{*}{$\underset{\mathrm{pH}}{\text { Optimum }}$} & \multirow{2}{*}{$\begin{array}{l}\text { Optimum } \\
\text { temp }\left({ }^{\circ} \mathrm{C}\right)\end{array}$} & \multirow{2}{*}{$\begin{array}{c}\text { Growth } \\
\text { substrate(s) }\end{array}$} & \multicolumn{2}{|c|}{ Growth requirements } & \multirow{2}{*}{$\underset{\text { layers }^{b}}{S}$} & \multirow[b]{2}{*}{ Reference } \\
\hline & & & & & $\begin{array}{c}\text { Organic } \\
\text { compound }(\mathrm{s})^{a}\end{array}$ & Ion & & \\
\hline M. wolfeii & I & 6.8 & 60 & $\mathrm{H}_{2}+\mathrm{CO}_{2}$ & YE & $\mathbf{W}$ & - & 29 \\
\hline "M. defluvium" ADZ & I & 7.2 & 60 & $\mathrm{H}_{2}+\mathrm{CO}_{2}$, formate & & & - & 14 \\
\hline "M. thermoflexum" IDZ & I & 7.9 & 55 & $\mathrm{H}_{2}+\mathrm{CO}_{2}$, formate & & & + & 14 \\
\hline M. thermoaggregans & II & 7.2 & 65 & $\mathrm{H}_{2}+\mathrm{CO}_{2}$ & CA, YE & & - & 3 \\
\hline M. thermophilum $\mathbf{M}^{\mathrm{T}}$ & II & 7.5 & 58 & $\mathrm{H}_{2}+\mathrm{CO}_{2}$ & CoM & $\mathrm{Ni}$ & - & 16 \\
\hline M. thermoautotrophicum $\Delta \mathbf{H}^{\mathrm{T}}$ & III & 7.5 & 65 & $\mathrm{H}_{2}+\mathrm{CO}_{2}$ & & & - & 32 \\
\hline M. thermoformicicum $\mathrm{Z}-245^{\mathrm{T}}$ & III & 7.5 & 55 & $\mathrm{H}_{2}+\mathrm{CO}_{2}$, formate & & & - & 33 \\
\hline M. thermoalcaliphilum & III & 8.3 & 60 & $\mathrm{H}_{2}+\mathrm{CO}_{2}$ & & & - & 4 \\
\hline Methanobacterium sp. strain DV & III & 8.3 & 65 & $\mathrm{H}_{2}+\mathrm{CO}_{2}$ & & & - & 16 \\
\hline Methanobacterium sp. strain F-1 & III & 7.6 & 58 & $\mathrm{H}_{2}+\mathrm{CO}_{2}$, formate & & & - & This paper \\
\hline Methanobacterium sp. strain 7VF & III & 7.4 & 60 & $\mathrm{H}_{2}+\mathrm{CO}_{2}$, formate & & & - & This paper \\
\hline Methanobacterium sp. strain Z-1201 & III & 7.5 & 58 & $\mathrm{H}_{2}+\mathrm{CO}_{2}$ & & & - & 33 \\
\hline Methanobacterium sp. strain Z-1901 & III & 7.5 & 60 & $\mathrm{H}_{2}+\mathrm{CO}_{2}$ & & & - & 33 \\
\hline
\end{tabular}

a YE, yeast extract; CA, Casamino Acids; CoM, coenzyme M.

$b+$, present; - , absent.

TC5E and $M$. thermoformicicum FTF have homology coefficients $(70$ and $50 \%)$ which are similar to our coefficients (Fig. 3). The level of protein pattern relatedness between members of the genera Methanosarcina and Methanobacterium is only $20 \%(26)$, which is in agreement with our data (data not shown).

Thus, the protein electrophoresis method and numerical analysis of electropherograms are suitable for differentiation and identification of thermophilic Methanobacterium strains. Because of the limited number of phenotypic characteristics that can be used for comparison of methanogens, comparative analysis of electropherograms provides a rapid means for determining the relationships between new isolates and established species.

Immunological fingerprinting. All 13 thermophilic Methanobacterium strains studied were antigen fingerprinted with the polyclonal antibody probes for 10 reference methanogens (Table 4). Cross-reactions showed that antisera were species specific.

A comparative immunological analysis performed with newly isolated and typical thermophilic Methanobacterium strains showed that this group is serologically diverse.

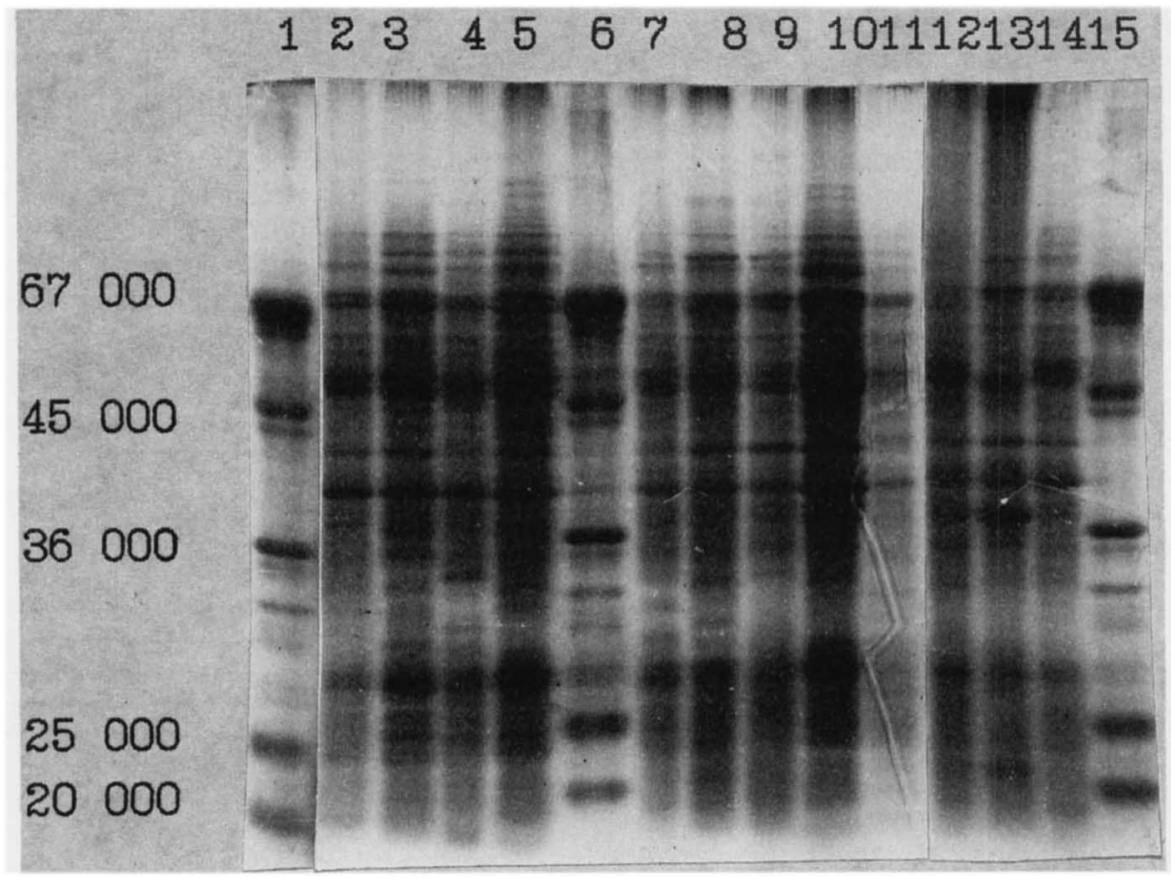

FIG. 2. Electrophoretic analysis of whole-cell proteins of thermophilic Methanobacterium strains. Lanes 1,6 , and 15 contained the following molecular weight standards: bovine albumin (molecular weight, 67,000), egg albumin $(45,000)$, lactate dehydrogenase $(36,000)$, chymotrypsin $(25,000)$, and trypsin inhibitor $(20,000)$. Lane $2, M$. thermoautotrophicum $\Delta \mathbf{H}^{\mathrm{T}}$; lane 3 , Methanobacterium sp. strain Z-1901; lane 4, Methanobacterium sp. strain Z-1201; lane 5, M. thermoautotrophicum DV; lane 7, M. thermoformicicum Z-245"; lane 8, "M. defluvium" ADZ; lane 9, “M. thermoflexum" IDZ; lane 10, Methanobacterium sp. strain F-1; lane 11, Methanobacterium sp. strain 7VF; lane $12, M$. thermoaggregans DSM $3266^{\mathrm{T}}$; lane $13, M$. wolfei DSM $2970^{\mathrm{T}}$; lane $14, M$. thermoalcaliphilum AC60 ${ }^{\mathrm{T}}$. 


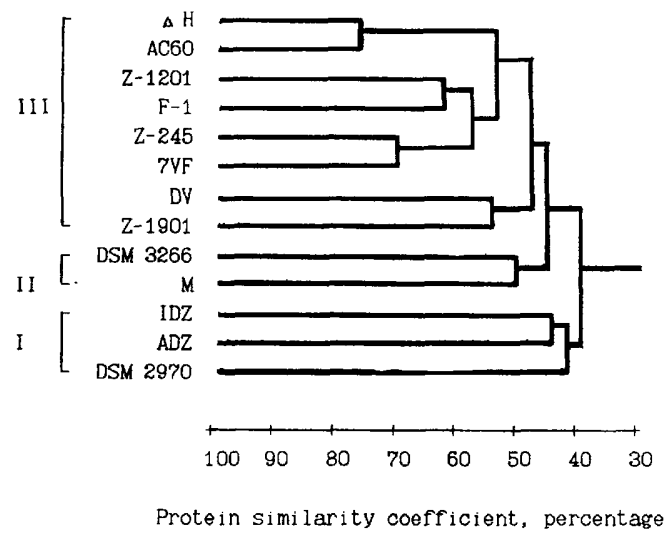

FIG. 3. Dendrogram based on $C_{s}$ values obtained by a comparative whole-cell protein electrophoretic analysis of members of the 13-strain matrix. The roman numerals indicate clusters. The species assignments of the strains are shown in Table 1.

Our data showed that $M$. thermophilum $\mathrm{M}^{\mathrm{T}}$ reacted slightly only with $M$. thermoaggregans (+2 reaction). Because of this and because of distinct physiological properties (Table 3), the former organism was described as a new species, $M$. thermophilum (16). None of the fingerprints in the reference group was similar to that of isolate $\mathrm{ADZ}$, since the latter did not react with any of the polyclonal antibody probes tested. " $M$. thermoflexum" IDZ reacted weakly with $M$. thermoautotrophicum $\Delta \mathrm{H}^{\mathrm{T}}$ (+1 reaction). $M$. wolfeii and $M$. thermoaggregans were relatively distinct, which agrees with their present taxonomic positions $(3,4,14,16,29)$.

Strain Z-1901 reacts with serum of $M$. thermoautotrophicum $\Delta \mathrm{H}^{\mathrm{T}}$ (+2 reaction). Strain Z-1201 shares common antigenic determinants with $M$. thermoautotrophicum $\Delta \mathrm{H}^{\mathrm{T}}$ (+1 reaction), strain DV $(+1)$, and $M$. thermoformicicum $\mathrm{Z}-245^{\mathrm{T}}(+1)$. These results agree with the results of previous immunological studies (2).

M. thermoautotrophicum $\Delta \mathbf{H}^{\mathrm{T}}, M$. thermoalcaliphilum $\mathrm{AC} 60^{\mathrm{T}}, M$. thermoformicicum Z-245 ${ }^{\mathrm{T}}$, and strains DV, F-1, and TVF constitute an antigenically coherent group of related organisms with nonspecific cross-reactions. All of the organisms in this group share common antigenic determinants. The data concerning the immunological relatedness of strains $\mathrm{Z}-245^{\mathrm{T}}$ and DV with $M$. thermoautotrophicum $\Delta \mathrm{H}^{\mathrm{T}}$ are in accord with data in other publications $(2,16,27)$.

The taxonomic system for methanogens obtained on the basis of the results of immunological fingerprinting coincides with the organization of methanogens based on 16S rRNA analysis (8).

Thus, our results from a comparative immunological analysis of thermophilic Methanobacterium strains demonstrate (i) that there is a correlation between the results of DNADNA hybridization and the results of a numerical analysis of whole-cell protein profiles (Fig. 1 and 3); (ii) the antigenic uniqueness of $M$. wolfeii, $M$. thermoaggregans, $M$. thermophilum, and strains ADZ and IDZ; and (iii) the serological similarity of $M$. thermoalcaliphilum and $M$. thermoautotrophicum $\Delta \mathrm{H}^{\mathrm{T}}$.

Taxonomy of $\boldsymbol{M}$. thermoalcaliphilum. The $\mathrm{G}+\mathrm{C}$ content of $M$. thermoalcaliphilum $\mathrm{AC}^{\mathrm{T}}$ which we obtained is about 10 mol\% higher than the value published previously (4), and the mean base compositions of DNAs from strains of $M$. thermoautotrophicum ranged from 49.9 to $50.78 \mathrm{~mol} \% \mathrm{G}+\mathrm{C}$.

The interspecies level of binding was found to be 10 to $45 \%$ in Methanobacterium spp. For comparison, binding levels of $10 \%$ are commonly found between members of the genus Methanogenium (31). Binding levels of 100 to $101 \%$ have been reported among Methanothrix strains (28).

Degrees of binding of 70 to $98 \%$ indicate that methanogenic bacteria must be placed in one species. The close DNA relationship between $M$. thermoautotrophicum $\Delta \mathrm{H}^{\mathrm{T}}$ and $M$. thermoalcaliphilum $\mathrm{AC}^{\mathrm{T}}{ }^{\mathrm{T}}$ (level of homology, 99\%) indicates that these organisms belong to one genospecies.

The morphologies and temperature ranges of these strains are very similar. Some difference was found in the $\mathrm{pH}$ optima (Table 3). For example, strain DV, identified as $M$. thermoautotrophicum, is an alcaliphilic organism (16). In addition, the protein patterns of $M$. thermoalcaliphilum are specific to the $M$. thermoautotrophicum group (Fig. 2 and 3).

Antiserum to $M$. thermoalcaliphilum $\mathrm{AC}^{\mathrm{T}} \mathrm{T}^{\mathrm{T}}$ cross-reacts intensely with $M$. thermoautotrophicum $\Delta \mathrm{H}^{\mathrm{T}}$ (+3 reaction), $M$. thermoformicicum Z-245 $(+3)$, and strain F-1 $(+3)$. Thus, $M$. thermoalcaliphilum and $M$. thermoformicicum $\mathrm{Z}-245^{\mathrm{T}}$ are closely related to $M$. thermoautotrophicum. Recently, because of immunological and DNA similarities, $M$. thermoformicicum $\mathrm{Z}-245^{\mathrm{T}}$ was reclassified as a reference strain of $M$. thermoautotrophicum (27).

TABLE 4. Levels of antigenic relatedness as determined with antibodies for thermophilic Methanobacterium strains and reference cultures

\begin{tabular}{|c|c|c|c|c|c|c|c|c|c|}
\hline \multirow[b]{2}{*}{ Reference strain } & \multicolumn{9}{|c|}{ Intensity of reaction with antibody for strain: } \\
\hline & $\Delta \mathbf{H}^{\mathrm{T}}$ & DV & $\mathrm{Z}-245^{\mathrm{T}}$ & $\mathrm{AC}^{\mathrm{T}} 0^{\mathrm{T}}$ & $\begin{array}{l}\text { DSM } \\
3266^{T}\end{array}$ & $M^{\mathbf{T}}$ & $\begin{array}{c}\text { DSM } \\
2970^{T}\end{array}$ & $\mathrm{ADZ}$ & IDZ \\
\hline M. thermoautotrophicum $\Delta \mathrm{H}^{\mathrm{T}}$ & 4 & 2 & 3 & 3 & 0 & 1 & 0 & 0 & 0 \\
\hline M. thermoautotrophicum DV & 4 & 4 & 1 & 2 & 1 & 0 & 0 & 0 & 0 \\
\hline Methanobacterium sp. strain F-1 & 2 & 0 & 3 & 3 & 0 & 0 & 0 & 0 & 0 \\
\hline Methanobacterium sp. strain Z-1901 & 2 & 0 & $\mathrm{ND}^{a}$ & 0 & 0 & 0 & 0 & 0 & 0 \\
\hline Methanobacterium sp. strain Z-1201 & 1 & 1 & 1 & 0 & 0 & 0 & 0 & 0 & 0 \\
\hline Methanobacterium sp. strain 7VF & 3 & 0 & 2 & 0 & 0 & 0 & 0 & 0 & 0 \\
\hline M. thermoformicicum $\mathrm{Z}-245^{\mathrm{T}}$ & 3 & 2 & 4 & 3 & 1 & 0 & 0 & 0 & 0 \\
\hline M. thermoalcaliphilum $\mathrm{AC} 60^{\mathrm{T}}$ & 3 & 0 & 2 & 4 & 1 & 0 & 0 & 0 & 0 \\
\hline M. thermoaggregans DSM $3266^{\mathrm{T}}$ & 0 & 0 & 1 & 1 & 4 & 0 & 0 & 0 & 0 \\
\hline M. thermophilum $\mathrm{M}^{\mathrm{T}}$ & 0 & 0 & 0 & 0 & 2 & 3 & 0 & 0 & 0 \\
\hline M. wolfeii DSM $2970^{\mathrm{T}}$ & 0 & 0 & 0 & 1 & 0 & 1 & 4 & 0 & 0 \\
\hline “M. defluvium" $\mathrm{ADZ}$ & 0 & 0 & 0 & 0 & 0 & 0 & 0 & 4 & 0 \\
\hline "M. thermoflexum" IDZ & 1 & 0 & 0 & 0 & 0 & 0 & 0 & 0 & 4 \\
\hline
\end{tabular}

${ }^{a} \mathrm{ND}$, not determined. 
On the basis of the phenotypic and genotypic similarities of $M$. thermoalcaliphilum and $M$. thermoautotrophicum, these organisms should be considered members of the same species. We propose that the name $M$. thermoalcaliphilum is a synonym of $M$. thermoautotrophicum.

Thus, the use of three independent taxonomic methods showed that (i) the thermophilic Methanobacterium strains are genotypically, phenotypically, and antigenically diverse; (ii) the most distinct organisms are $M$. wolfeii, $M$. thermoaggregans, $M$. thermophilum, " $M$. defluvium" $\mathrm{ADZ,} \mathrm{"} M$. thermoflexum" IDZ, and $M$. thermoautotrophicum $\Delta \mathrm{H}^{\mathrm{T}}$; (iii) newly isolated thermophilic strains F-1 and 7VF belong to $M$. thermoautotrophicum; and (iv) the name $M$. thermoalcaliphilum should be regarded as a synonym of $M$. thermoautotrophicum.

\section{ACKNOWLEDGMENT}

We thank T. N. Zhilina for supplying thermophilic strains $Z-245^{\mathrm{T}}$, Z-1201, and Z-1901.

\section{REFERENCES}

1. Balch, W. E., G. E. Fox, L. J. Magrum, C. R. Woese, and R. S. Wolfe. 1979. Methanogens: reevaluation of a unique biological group. Microbiol. Rev. 43:260-296.

2. Bezrukova, L. V., A. Y. Obraztsova, and T. N. Zhilina. 1989. Immunological assay of bacterial strains producing methane. Mikrobiologiya 58:92-98.

3. Blotevogel, K.-H., and U. Fischer. 1985. Isolation and characterization of a new thermophilic and autotrophic methane producing bacterium, Methanobacterium thermoaggregans. Arch. Microbiol. 142:218-222.

4. Blotevogel, K.-H., U. Fischer, M. Mocha, and S. Jannsen. 1985. Methanobacterium thermoalcaliphilum spec. nov., a new moderately alcaliphilic and thermophilic autotrophic methanogen. Arch. Microbiol. 142:211-217.

5. Boone, D. R., and W. B. Whitman. 1989. Proposal of minimal standards for describing new taxa of methanogenic bacteria. Int. J. Syst. Bacteriol. 38:212-219.

6. Brandis, A., R. K. Tauer, and K. O. Stetter. 1981. Relatedness of the strain $\mathrm{H}$ and Marburg of Methanobacterium thermoautotrophicum. Zentralbl. Bakteriol. Parasitenkd. Infektionskr. Hyg. Abt. 1 Orig. Reihe C 1:311-317.

7. Chuvilskaya, N. A., A. Y. Obraztsova, B. F. Belokopytov, K. S. Laurinavichus, Y. Y. Atakishieva, and V. K. Akimenko. 1989. Immunological study of thermophilic anaerobic bacteria. Mikrobiologiya 58:489-493.

8. Conway de Macario, E., M. J. Wolin, and A. J. L. Macario. 1981. Immunology of the archaebacteria that produce methane gas. Science 214:74-75.

9. De Ley, J., H. Cattoir, and A. Reynaerts. 1970. The quantitative measurement of DNA hybridization from renaturation rates. Eur. J. Biochem. 12:133-142.

10. Dijkshoorn, L., I. Tjerberg, B. Pot, M. F. Michel, J. Ursing, and K. Kersters. 1990. Numerical analysis of cell envelope protein profiles of Acinetobacter strains classified by DNA-DNA hybridization. Syst. Appl. Microbiol. 13:338-344.

11. Garcia, J. L. 1990. Taxonomy and ecology of methanogens. FEMS Microbiol. Rev. 87:297-308.

12. Kersters, K., and J. De Ley. 1975. Identification and grouping of bacteria by numerical analysis of their electrophoretic protein patterns. Can. J. Microbiol. 87:333-342.

13. König, H., R. Kralik, and O. Kandler. 1982. Structure and modifications of the pseudomurein in Methanobacteriales. Zentralbl. Bakteriol. Parasitenkol. Infektionskr. Hyg. Abt. 1 Orig. Reihe C3:179-191.

14. Kotelnikova, S. V., A. Y. Obraztsova, G. M. Gongadze, and K. S. Laurinavichus. Methanobacterium thermoflexum sp. nov. and Methanobacterium defluvium sp. nov., thermophilic rodshaped methanogens isolated from the pilot-scale plant for digesting the metacrilic wastes. Syst. Appl. Microbiol., in press.
15. Laemmli, U. K. 1970. Cleavage of structural proteins during the assembly of the head of bacteriophage T4. Nature (London) 227:680-685.

16. Laurinavichus, K. S., S. V. Kotelnikova, and A. Y. Obraztsova. 1988. New species of thermophilic methane-producing bacteria, Methanobacterium thermophilum. Microbiology (Engl. Transl. Mikrobiologiya) 57:832-838.

17. Macario, A. J. L., and E. Conway de Macario. 1983. Antigenic fingerprinting of methanogenic bacteria with polyclonal antibody probes. Syst. Appl. Bacteriol. 4:451-458.

18. Marmur, J. J. 1961. A procedure for the isolation of deoxyribonucleic acid from microorganisms. Mol. Biol. 3:208-218.

19. Marmur, J. J., and P. Doty. 1961. Determination of the base composition of deoxyribonucleic acid from its thermal denaturation temperature. J. Mol. Biol. 5:109-118.

20. Mitchell, R. M., L. A. Loeblich, L. C. Klotz, and A. R. Lorblich. 1979. DNA organization of Methanobacterium thermoautotrophicum $\Delta \mathrm{H}$. Science 204:1082-1084.

21. Nolling, J., M. Fridjlic, and M. De Vos. 1991. Isolation and characterization of plasmids from different strains of Methanobacterium thermoformicicum. J. Gen. Microbiol. 137:19811986.

22. Owen, R. S., and P. G. H. Jackman. 1982. The similarities between Pseudomonas paucimobilis and allied bacteria derived from analysis of deoxyribonucleic acids and electrophoretic protein patterns. J. Gen. Microbiol. 128:2945-2954.

23. Pot, B., M. Gillis, B. Hoste, A. Van De Velde, F. Bercaert, $K$. Kersters, and J. De Ley. 1989. Intra- and intergeneric relationships of the genus Oceanospirillum. Int. J. Syst. Bacteriol. 39:23-34.

24. Scherer, P., and H. Kneifel. 1983. Distribution of polyamines in methanogenic bacteria. J. Bacteriol. 154:1315-1322.

25. Sowers, K. R., J. L. Johnson, and G. J. Ferry. 1984. Phylogenetic relationships among the methylotrophic methane-producing bacteria and emendation of the family Methanosarcinaceae. Int. J. Syst. Bacteriol. 34:444-450.

26. Thomas, I., D. Verrier, H. C. Dubourguier, N. Hanoune, and C. Langrand. 1986. Numerical analysis of whole-cell protein patterns of methanogens, p. 245. In H. C. Dubourguier et al. (ed.), Biology of anaerobic bacteria. Elsevier Science Publishers B. V., Amsterdam.

27. Touzel, J. P., E. Conway de Macario, J. Nölling, W. M. De Vos, N. Zhilina, and A. M. Lysenko. 1992. DNA relatedness among some thermophilic members of the genus Methanobacterium: emendation of the species Methanobacterium thermoautotrophicum and rejection of Methanobacterium thermoformicicum as a synonym of Methanobacterium thermoautotrophicum. Int. J. Syst. Bacteriol. 42:408-412.

28. Touzel, J. P., G. Prensier, J. L. Roustan, I. Thomas, H. C. Dubourguer, and G. Albagnac. 1988. Description of a new strain of Methanothrix soengenii and rejection of Methanothrix concilii as a synonym of Methanothrix soehngenii. Int. J. Syst. Bacteriol. 38:30-36.

29. Winter, J., C. Lerp, H.-P. Zabel, F. X. Wildenauer, H. König, and F. Schindler. 1984. Methanobacterium wolfei, sp. nov., a new tungsten-requiring, thermophilic, autotrophic methanogen. Syst. Appl. Microbiol. 5:457-466.

30. Wolin, E. A., M. J. Wolin, and J. Wolfe. 1963. Formation of methane by bacterial extracts. J. Biol. Chem. 238:2882-2886.

31. Xun, L., D. R. Boone, and R. A. Mah. 1989. Deoxyribonucleic acid study of Methanogenium and Methanocorpusculum species, emendation of the genus Methanocorpusculum, and transfer of Methanogenium aggregans to the genus Methanocorpusculum as Methanocorpusculum aggregans comb. nov. Int. J. Syst. Bacteriol. 39:109-111.

32. Zeikus, J. G., and R. S. Wolfe. 1972. Methanobacterium thermoautothrophicum sp. nov., an anaerobic, autotrophic, extreme thermophile. J. Bacteriol. 109:707-713.

33. Zhilina, T. N., and S. A. Illarionov. 1984. Isolation and comparative characteristics of methanogens assimilating formate with the description of Methanobacterium thermoformicicum sp. nov. Mikrobiologiya 53:785-790. 